\title{
CRITICISMS AND DISCUSSIONS.
}

\section{THE CONFLICT OF RACES: A REPLY TO CRITICISMS.}

In the course of my later studies for a Theory of the Origin, History, and Future of Civilisation, the Conflict of Races has appeared to me to be a fact of fundamental importance. So general a phrase, however, may cover very different theories. So far as I am aware, the theory I have set forth under this name stands alone as a Theory of the Origins of Civilisation. But I read with great interest Professor Fiamingo's paper in your last issue adversely criticising the whole conception of a "Conflict of Races, Classes, and Societies." And I would now beg to be allowed to criticise his criticisms from the point of view of my own theory. ${ }^{1}$

To know the nature, and hence the history and future of any set of phenomena we must, as Aristotle insisted with profound insight, endeavor to ascertain its origin. And theories of civilisation can have little, if any, value without knowledge of the conditions under which it originated. Now the chief theories as to the origin of civilisation may be classified and characterised as ( 1 ) the Family-Origin Theory of Plato and Aristotle; then after the long night of the Christian Dark Ages, (2) the Sixteenth Century Conquest-Origin Theory of Bodin : (3) the Seventeenth and the Eighteenth Century Contract-Origin Theories of Hooker, Grotius, Hobbes and Locke, etc., to Rousseau; and (4) the Savage-Origin Theories now set forth as, for instance, by Dr. Tylor, Sir John Lubbock, and Mr. Spencer. In these current theories civilisation is more or less explicitly regarded as having originated spontaneously and sporadically somewhere, somehow, and somewhen at, it may be,

1 This theory I first fully stated in 1887 in papers read at the April meeting of the Royal His torical Society, and the September meeting of the British Association, and afterwards published in full or in abstract in their respective Transactions. I had, however, partially stated the theory in previous publications,-only a development, as it is, of my New Philosophy of History, published in 1873 . In exposition of this theory $I$ have also, since 1887 , both written papers published in abstract or otherwise in the Transactions of the International Congresses of Orientalists, the Transactions of the International Folklore Congress, the Archoological Review, Folklore, and other periodicals, and delivered lectures ("The Conflict of Races: A New Theory of the Origins of Civilisation") at the Philosophical Institution, Edinburgh, reported in the Scotsman from November 1893 to January 1894 . And 1 may refer likewise to the essays in my editions of The Women of Turkey and their Folklore, Vol. I., 1890, Vol. II., 1891; Greek Folksongs, 1885 and 1888 ; and Greek Folkpoesy, 1896 . 
various different times and places, and all entirely unconnected with each other. And such appears to be the view of Professor Fiamingo. But the recent results of Assyriological and Egyptological research have put the question as to the origins of civilisation, and therewith as to the conflict of races, on an entirely new basis. For I think I can say without fear of authoritative contradition that the main tendency of the results of modern research with reference to the origins of civilisation is to show that it originated in Chaldea and in Egypt at a date which may be at least approximately ascertained, and that from these twin centres all the civilisations, of the Old World at least, were directly or indirectly derived. The question, therefore, as to the origins of civilisation is now one of a scientific rather than merely speculative character. It is the definite question as to the conditions of the origin of definite primary civilisations; and to this question an increasingly verifiable answer is given by the rapidly accumulating results of ethnological and archæological research. For whatever speculative opinion may be as to the Conflict nf Races, not merely the ancient traditions preserved by Berosus, but such physical facts as differences of skull and skeleton, differences of position in burial, and differences in painted, engraved, and sculptured portraitures show that unquestionably one of the conditions of the Origin of Civilisation was a difference and conflict of higher and lower races.

The question then arises as to the importance of this condition, and whether it was or not the chief and determining condition of that new species of human association which we term civilisation. But no scientific argument is possible without a preliminary definition of its subject, and such a definition as shall be but a generalisation of the facts investigated. Now, considering the facts revealed by investigation of Chaldean and Egyptian origins, and by a survey of civilisations generally, civilisation may, I think, be defined as such a relation between higher and lower races or classes of the same race as results in enforced organisation of food-production and distribution, followed by such economic conditions as make possible the planning and execution of great public works, the invention and development of thonetic writing, and the initiation of intellectual development generally. For I submit that the ultimate economic fact which distinguishes the civilised from the savage state is the change from the precarious savage mode of subsistence on wild-growing fruits gathered, and wild-running game killed as hunger urges, to the cultivation of plants and the domestication of animals, and the storage and regulated distribution of the food-supplies thus obtained. More briefly this is expressed by $\mathrm{Mr}$. Payne in his great work (The History of the New World Called America) as "the substitution of an artificial for a natural basis of subsistence." And though he believes-what $I$ doubt-that the ancient American civilisations were wholly unconnected with, or influenced by, those of the Old World, yet he agrees with me that, in the New World also, as, I believe, certainly in the Old, this great economic change was effected under the direction of-so far at least as governing capacities were concerned-a higher race. Of course, the 
change from a natural to an artificial basis of subsistence may be partially effected in some tribes under the direction of native chiefs of superior intelligence and power of command. But what I submit is, that there is the reverse of any evidence of such a change having been effected on the large and systematic scale necessary to found a civilisation save under the direction of rulers belonging to a race either etbnologically or economically higher than that from which the labor and thrift were exacted which are no less naturally hateful than economically necessary.

"If it had not occupied the basin of the Mediterranean and united in itself all "the useful knowledge which belonged to the three continents of antiquity, the " white race," says Professor Fiamingo, "would never have been able to give to " the world the cosmopolitan civilisation which it has given." No doubt. But also if the race "occupying the basin of the Mediterranean" had been the black race, it would, judging from our knowledge of the race, not only in the present but during past thousands of years, certainly not have "united in itself all the useful knowledge, etc." And to say that "the civilisation which arose along the Mediterranean was not in fact due to this or that race, but was a result of natural geographic conditions," is simply to ignore all the vast mass of facts which prove that the ruling classes of Chaldea and Egypt belonged to the white race; that those of the Mediterranean civilisations belonged also to that race; and that without the commanding power which the white race has everywhere shown itself capable of exerting over other races, the fundamental economic condition of civilisation-the organisation of food-production and distribution-would never have been realised. It is not worth disputing whether it is, or not, "quite rare," as affirmed by Professor Fiamingo, that "peoples inhabiting contiguous regions present quite different ethnographic characteristics." It is sufficient to remark that the primary civilisations did, as a matter of fact, originate just at the line of junction of two regions inhabited respectively by peoples-the Equatorian Blacks and the Eurasian Whites-so different in their ethnographic characteristics that according to the ordinary practice of zoölogical classification they would be distinguished as different species. Who the "nations belonging to the white race" were or are who have, as the Professor asserts, "founded civilisations much inferior to the civilisation of the yellow race, or even of the black," he does not tell us, and I cannot imagine. For I do not know of any civilisation, save perhaps the ancient American, which has been founded otherwise than under the direction of men belonging to one or other of the white races. By white races I mean races with either long or short heads, high noses, unprojecting jaws, long hair and beards, and light colored skins. And for the races thus generally distinguishable-and of which the three great historic branches are: (I) the Archaians (as I have named the white races of the earlier civilisations), (2) the Semites, and (3) the Aryans-I have proposed the term Hypenetian, from inmint $\eta$ " a bearded man."

I shall but add that in countries which have reached the higher stages of civilisation the old differences of race have disappeared in the sentiment of a common 
nationality arising partly from general intermarriage and partly from equal laws But the conflict of races has ceased only in a transformation into a conflict of classes, an economic conflict of workers and capitalists, - a conflict of so very real and stern a character as to make Professor Fiamingo's talk of "the pretended Conflict of Classes" almost amusing. This conflict has still to run its course; but in the future we may foresee yet another transformation of the social conflict, - a conflict not of different races and classes in fierce opposition, but of different aptitudes in voluntary co-operation, in their due spheres, for the common good,-a sociological analogous to the biological, conflict of anabolic and katabolic energies in the metabolism of a healthy organism.

HASLEMERE, ENGLAND.

\section{J. S. Stuart-Glennie.}

\section{ANIMAL AUTOMATISM AND CONSCIOUSNESS.}

The interest of Prof. Lloyd Morgan's October article lies mainly in its deterministic significance. Some want of clearness, noticeable here and there, is caused by uncertainty as to the precise sense in which the late Professor Huxley used the ambiguous term "automata," and by a rather intricate effort to decide this, and to reach a better definition.

The word "automatic" "has received," says Dr. Augustus Waller, "two dia"metrically opposed meanings, viz, (I) Self-moving, self-arising, spontaneous, in

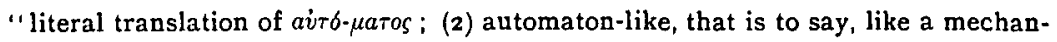
"ism that appears to be self-moving, but that we know to be moved by secret "springs and hidden keys." 1 Professor Huxley seems to have used "automata" in the second of these senses, as a compact synonym for "machines which appear to be, but are not, self-moving." Professor Morgan, however, thinks that it may be "fairly inferred from what is explicitly or implicitly contained" in Professor Huxley's essay that he used the term as "applicable to any mechanism all the workings of which at any given time are explicable in terms of physical causation." $\mathrm{He}$ then objects to this "inferred" definition because, he thinks, it is not in accordance with general usage, not helpful in the study of animal life, and does not preserve the spirit of Descartes's teaching. And he proposes (p. 8) this "more restricted" definition: "Automatic action is that which is performed without the "immediate and effective intervention of those molecular changes in the cerebral "cortex which are accompanied by consciousness (such intervention being rendered "possible by association)."

The root of the matter seems to lie not in the subsidiary inquiry, How should "automata" be defined? but in the much deeper question, Does volition cause and control "voluntary" acts ? 